\title{
Job Satisfaction and Achievement of Maqasid Al- Sharia: A Case Study in Takaful Keluarga Yogyakarta
}

\author{
Tulasmi \\ Department of Islamic Economics \\ Islamic University of Indonesia \\ Yogyakarta, Indonesia \\ tulasmi@uii.ac.id
}

\author{
Martini Dwi Pusparini \\ Department of Islamic Economics \\ Islamic University of Indonesia \\ Yogyakarta, Indonesia
}

\author{
Puji Lestari \\ Department of Islamic Economics \\ Islamic University of Indonesia \\ Yogyakarta, Indonesia
}

\author{
Yuli Andriansyah \\ Department of Islamic Economics \\ Islamic University of Indonesia \\ Yogyakarta, Indonesia
}

\begin{abstract}
This study aims to analyze Takaful Keluarga Yogyakarta employee's job satisfaction and achievement of maqasid al-sharia. This study used a qualitative method by describing data, analyzing data and making conclusions. Data collection technique was carried out through observation, interviews and documentation. The level of Takaful Keluarga Yogyakarta employee's job satisfaction and maqasid al-sharia in terms of job satisfaction for work, rewards, supervisor supervision, co-workers, and promotions, and maqasid al-sharia are maintenance of religion, soul, mind, offspring, and property. The results of this study indicate that the level of Takaful Keluarga Yogyakarta employee's job satisfaction and maqasid al-sharia is in accordance with Sharia principles. However, for the job satisfaction, there are still items that have not been reached: work, supervisor supervision, co-workers, and promotion opportunities. Whereas for maqasid al-sharia, the items that have not been reached are the maintenance of mind and offspring.
\end{abstract}

Keywords: Islamic Insurance, Job Satisfaction, Maqasid AlSharia, Takaful Keluarga Yogyakarta

\section{INTRODUCTION}

The National Sharia Board states that takaful is an effort to protect and help each other among a number of people which is done through investment in assets (tabarru) that provide a pattern of taking certain risks through contract (agreement) in accordance with sharia. Sharia insurance products have been introduced in Indonesia since 1994 with the pioneer of a sharia-based insurance company, Asuransi Takaful, which was established on August 4, 1994. There are many types and benefits offered by insurance, where each insurance company has a variety of features and advantages on each product they spend.

Takaful Keluarga is a pioneer of sharia life insurance companies in Indonesia which has been operating since 1994, products issued is in accordance with sharia include life protection, health protection, children's education planning, old age planning and become the best partner in investment planning. This research was conducted at Takaful Keluarga at Yogyakarta to find out whether its employee's job satisfaction has been achieved as a whole. In addition, this study also links job satisfaction with maqasid al-sharia because an Islamic financial institution is obliged to maintain a balance between the company's efforts to achieve profit and the objectives of sharia.

Efforts to improve employee performance to be more effective are very necessary. Companies need to know the factors that affect employee performance and then support them at work. If the support from the company is felt to not be able to provide satisfaction for employees, the company must find a solution so as not to affect performance [1]. Every company strives to improve and develop the company with various efforts to improve employee performance. Employees who feel satisfied or in accordance with their work always work well, their work performance will increase, and that with high work performance, employee job satisfaction will indirectly increase as well [2].

Maqashid al-sharia is a general goal to be achieved in sharia and applied to everyday life. It is one of the important concepts in the study of Islamic law. The essence of it is to realize goodness while avoiding evil, attracting benefits and rejecting madharat. It is included in maslahah (maslahat) because the stipulation on Islamic law must lead to benefit. Allah SWT as shari 'who establishes the Sharia does not just create laws and rules. But laws and rules are created with a specific purpose and purpose. Ibn Qayyim said that the purpose of sharia is to achieve the benefit of the world and the hereafter, because based on sharia it is justice, gets mercy, and gets wisdom from Allah SWT. Because every deviant problem comes from justice, mercy, maslahat, and wisdom not solely from the provisions of sharia [3].

\section{LITERATURE REVIEW}

Kionggono [4] found that CV Lancar Jaya employees were satisfied in their provider leadership, promotion and coworkers, but were not satisfied with the salary and work provided. Amrizal [5] shows service trends and innovations in the banking industry such as achievement, recognition, selfemployment, responsibility and progress, and continues to increase expectations of job satisfaction on service quality. 
The majority of banks improve this performance, as evidenced by the increase in the number of service improvement initiatives launched by banks. This study implies that, for managers to be able to measure improved performance they must be able to identify and focus on employees who present clear potential for long-term and have mutually beneficial relationships.

Febriadi [3] explained that the Maqasid al-sharia was not born suddenly, but passed various stages, namely: pre codification, and codification. The economic system is said to be successful and running if it can prosper the people. Then the economic system must be able to strive to achieve its main goal, namely its social welfare towards the community. The birth of Islamic banks is intended to realize the welfare of the people at large. By referring to this main objective, the term Maqasid al-sharia is the main support in every operational development and product in Islamic banks. Nurnazli [6] found that the Maqasid al-sharia refers to the act of achieving and protecting the benefits and good (masalih) for the sake of humans. The current practice of Islamic banks needs to incorporate maqasid al-sharia into their management strategies to ensure continuity in serving humanity in the future, as a confirmation of Sharia needs. Although profitability is very important and must be achieved, it is not the main goal. In Islam, the ultimate goal of each activity includes business activities in the end with the aim of achieving the goals of the maqasid al-sharia.

Imanda, Prihatini and Dewi [7] found that in general, respondents were satisfied with the performance of compensation, supervision, the work itself, work relations, and guaranteed employment of PT. Kharisma Ide Nusantara Garmindo Cibitung - Bekasi. However, there were still respondents who were not satisfied with the opportunity to leave given by the company, the supervision system using assistive devices, employee transportation facilities, adequate work equipment, and old age benefits. Nasrih [2] asserts that performance is a function of motivation and ability. To complete a task or work someone should have a certain degree of willingness and level of ability. A person's willingness and skills are not effective enough to do something without a clear understanding of what will be done and how to do it. Performance is the real behavior that is displayed by everyone as the work performance produced by employees in accordance with their role in the company. Employee performance is an important thing in the company's efforts to achieve its goals.

Mashareen, Supriyanto and Ivanti [8] show that $40 \%$ of PT. X employees have a moderate level of job satisfaction, and $37.5 \%$ of employees of PT. X has a low level of job satisfaction. In addition, the survey also found that male employees over the age of 40 tended to have high levels of job satisfaction. Meanwhile, employees with more than 1 year working period and employees who graduated from high school and higher education (Bachelor, Diploma) tend to have a high level of job satisfaction. Rosita and Yuniati [9] show that job satisfaction has a direct and significant effect on employee performance. Job satisfaction has a direct and positive effect on organizational commitment and organizational commitment has a positive and significant indirect effect between job satisfaction and employee performance.

\section{RESEARCH METHOD}

This study used a qualitative method to see whether the level of job satisfaction and achievement of maqasid al-sharia is in accordance with Islamic law or not. Qualitative data was obtained by observation, interviews, and documentation to employees in the Takaful Keluarga of Yogyakarta during August 2018. Instruments used when conducting interviews are draft interviews, recorders, pens and books or notes. The model questionnaire of Robbins and Judge [10] was utilized to measure job satisfaction based on five factors: job satisfaction, rewards, supervisor supervision, co-workers, and promotion opportunities. The data analysis technique was carried out using the Miles, Huberman and Saldaña [11] which stated that the activities in qualitative data analysis were carried out interactively and continued continuously to completion so that the data was saturated. Data analysis consisted of data reduction, data display and conclusion drawing / verification.

\section{RESEARCH LITERATURE}

\section{A. The level of Job Satisfaction at Takaful Keluarga Yogyakarta}

The job satisfaction has been achieved with the workload given by the company, according to the educational background, level of education, skills, abilities, and expertise possessed. In completing work, employees are always given freedom by superiors, the facilities provided by the company are quite satisfying and the work done plays an important role in the progress of the company and they feel proud of the work now. One employee said that there was a discrepancy with the background and level of education, skills, abilities and expertise because the employee had expertise in the field of public health. This means that job satisfaction on the job has been partially achieved and some have not been achieved with the desired employee.

\section{Satisfaction to Rewards}

All employees are already satisfied with the salary given by the company, because according to the workload and responsibilities that and the income provided by the company is in accordance with the work done. Salaries obtained in the form of financial and non-financial. For financial thing, the salary remained above $\mathrm{Rp} 6,000,000$ while the contract employee above Rp 1,000,000, while non-financial thing, it's from health insurance and Social Security Workers (Jamsostek) granted to employees and families of employees of companies as well as allowances and bonuses has been matched beyond the employee's basic salary. This shows that satisfaction with the rewards of all employees has been achieved as expected.

\section{Satisfaction with Supervisor}

Supervisors are always consistent and helpful in implementing rules for employees related to work. They also provide assistance when employees have difficulty in completing work, give awards to the success of employees when completing work and provide input when they have difficulty working and providing guidance for employees who do not understand the work provided. This shows that job satisfaction towards supervisor supervision has not been fully achieved because the boss in giving direction is not done directly but through email, telephone and WhatsApp so that 
communication between superiors and subordinates is less effective.

\section{Satisfaction to Partners}

Relationship between colleagues is well established, because every time there are difficulties in working, colleagues provide assistance directly. Tasks given to all employees can be resolved properly because of the support of colleagues, all colleagues are responsible for their work and always provide advice, support and assistance if other coworkers get into trouble while working. This shows that satisfaction with co-workers has not been fully achieved because one of the employees said that every job must have difficulties depending on the work provided.

\section{Promotion}

The opportunity is carried out objectively, the company provides the widest opportunity to have promotion without discrimination. It is not yet achieved because not all employees are given promotional opportunities from good work performance. Promotional opportunities are only at head office, branch offices and only recommend employees who will carry out promotions. This means that the opportunity for promotion has not been fully achieved because the one who provides promotion policy is the head office, the branch office that only recommends it.

\section{B. Maqasid al-sharia at Takaful Keluarga Yogyakarta}

Maslahah and Maqasid al-sharia in al-Syatibi's view are two important things in fostering and developing Islamic law. Maslahah is simply interpreted as a good action and can be accepted by a healthy mind, the meaning accepted by mind means that mind can clearly know the benefit [12]. Maqasid al-sharia can also be regarded as an Islamic view whether it is in accordance with the Sharia and Islamic law.

\section{Hifdhu Al-Din (Maintaning Religion)}

Maintenance of the religion of all employees has been achieved both from the five time obligatory prayers, paying zakat, fasting Ramadhan, being able to help save money for departing hajj, and the company provide opportunities for employees to attend Islamic holidays from Eid al-Fitr, Adha and other Islamic holidays. This is that the maintenance of religion has been fully achieved for all employees of the Takaful Keluarga of Yogyakarta.

\section{Hifdhu Al-Nafs (Caring for the Soul)}

Maintenance of the soul that all employees feel has been fully achieved starting from employees feeling safe while working in the family, the company also provides good, safe and easily accessible health facilities. By working in Takaful Keluarga Yogyakarta can provide assistance to meet family needs in a balanced manner and the income earned can help in repayment of housing and vehicles.

\section{Hifdhu Al-Aql (Maintaining Mind)}

Company provides opportunities for employees to take education again and training to improve employee knowledge to get a lot of knowledge and experience in work. This means that maintenance of mind has not been fully achieved because the employee explained that the branch office had not provided scholarships for study assignments for employees, but at the head office had provided scholarships for employees.

\section{Hifdhu Al-Nasl (Maintaining Offspring)}

Maintenance of offspring that the company provides benefits for the family, provides labor costs for employees / wives of employees and provides health costs for families of employees. This shows that maintenance of offspring has not been fully achieved because some employees say that family health costs must contribute themselves and the company has not provided educational scholarships for employees' children because they feel they are able to pay for their children's schooling.

\section{Hifdhu Al-Mal (Maintaining Property)}

All employees say has been fully achieved because the property actually comes from a way that is justified by Islam and protected by the Indonesian Ulema Council (MUI) and income received is in accordance with the performance and the work done does not harm other people but provides benefits to others. This shows that maintenance of property has been fully achieved for all company employees.

Based on the results above, it can be concluded that the suitability of employee job satisfaction with the real condition is quite appropriate. The facilities and services provided for employees are good. Then the job satisfaction of the employee is good, but some work is done is not in accordance with education and skills of the employee. Satisfaction with rewards is in accordance with what employees want. Satisfaction with supervisor supervision is appropriate, but some employees are not satisfied because the supervisor gives direct guidance. Satisfaction with co-workers is appropriate but some employees have not found difficulties because work is done in collaboration and promotion opportunities are appropriate but not all employees are given the opportunity to promote both promotions and company products.

Whereas seen from maqasid al-sharia towards the maintenance of religion and soul is appropriate because all employees perform the obligatory prayers on time, wear clothes that cover their genitals and employees feel safe working in Takaful Keluarga Yogyakarta. Maintenance of mind and offspring is appropriate but the branch office has not implemented learning scholarships for employees and educational scholarships for employees' children, and maintenance of property is appropriate because the assets and income received come from ways that are justified by Islam because they are protected by the Indonesian Ulema Council (MUI).

\section{DISCUSSION}

This study discusses the level of takaful keluarga employee's job satisfaction and achievement of maqasid alsharia in Yogyakarta. Job satisfaction is influenced by five factors: satisfaction with work, rewards, supervisor supervision, co-workers and promotion opportunities [10]. Previous research [4] stated that employees were satisfied with supervisor leadership, promotion and co-workers but were not satisfied with the salary and work provided by the company.

Another study [8] stated that $40 \%$ had a moderate level of satisfaction, and $37.5 \%$ a low level of satisfaction. Respondents were satisfied with the performance of 
compensation, supervision, work itself, work relations and job security. However, they were not satisfied with the opportunity to leave, the supervision system, transportation facilities, work equipment, and old age benefits [7]. Other finding suggested that job satisfaction has a direct and positive effect on organizational commitment and organizational commitment has a positive and significant indirect effect on job satisfaction on employee performance [9]. Tentama [1] stated that there was a positive and significant relationship between job satisfaction and performance. Nasrih [2] found that work performance produced by employees is in accordance with the role in the company and Amrizal [5] noted that the majority of banks improve performance can be proven through increasing the number of service initiatives provided by banks to the public. Maqasid al-sharia in the economic system must enable Muslims to strive for their main purpose of life: social welfare [3]. Previous finding has indicated that the application of Islamic values in Islamic banks will improve bank performance [13]. Nurnazli [6] also indicated that the ultimate goal of each activity both in business is to achieve benefit. Based on previous research, the focus was more on satisfaction or the maqasid only. However, this study focused on job satisfaction and maqasid al-sharia for company employees.

\section{CONLUSION}

Based on the results of research conducted at the Takaful Keluarga Yogyakarta, it can be concluded that the job satisfaction of its employees is measured through job satisfaction on work, rewards, supervisor supervision, coworkers and promotion opportunities. For job satisfaction on the work part has been achieved that has not been achieved in terms of background, level of education, skills, abilities and expertise of one employee. Satisfaction with rewards has been fully achieved. Satisfaction with supervisor supervision has been achieved but some employees say the boss gives direct guidance. Satisfaction with co-workers has been achieved but one employee said that every job must have difficulties depending on the work provided. Promotional opportunities have been achieved but not all employees are given promotional opportunities because they are seen from good work performance that will result in promotions for employees and superiors. Promotional opportunities are only provided by headquarters, branch offices and only recommend employees who will carry out promotions.

In order to achieve the maqasid al-shariah, it is measured through the variables of maintaining religion, soul, mind, offspring, and property. Maintenance of religion has been achieved because all employees carry out obligatory prayers on time, cover their genitals, pay zakat, fasting in Ramadan and celebrate Islamic holidays. Soul maintenance has been achieved because all employees feel safe working in the company. Mind maintenance has been achieved but some employees have not been achieved because the branch office has not provided scholarships for study assignments for employees while at the head office has provided employee scholarships. Maintenance of offspring has been achieved but some employees have not been achieved because the health costs for the family must contribute themselves and the company has not provided educational scholarships for children of employees because of the provisions of the head office. Maintenance of property has been achieved because all employees obtained property derived from ways that are justified by the Islamic religion and protected by the Indonesian Ulema Council (MUI).

\section{REFERENCES}

[1] Tentama F 2015 Peran kepuasan kerja terhadap kinerja pada guru pegawai negeri sipil (PNS) di Yogyakarta Jurnal Psikologi Undip 14(1) $1-8$

[2] Nasrih M L 2010 Analisis hubungan kepuasan kerja terhadap prestasi kerja karyawan Al-Iqtishad 2(1) 155-180

[3] Febriadi S R 2017 Aplikasi maqashid syraiah dalam bidang perbankan syariah Amwaluna 1(2) 231-245

[4] Kionggono A 2015 Studi deskriptif kepuasan kerja karyawan CV Lancar Jaya AGORA 3(2) 534-537

[5] Amrizal 2016 Quantitative and qualitative approach of banking performance measure based on job satisfaction for Islamic and conventional banks in Indonesia Balance 13(2) 63-81

[6] Nurnazli 2014 Penerapan kaidah maqashid syariah dalam produk perbankan syariah Ijtimaiyya 7(1) 1-21

[7] Imanda S N, Prihatini A E and Dewi R S 2012 Analisis tingkat kepuasan kerja karyawan Ilmu Administrasi Bisnis 1-8

[8] Mashareen, Supriyanto and Ivanti 2016 Survei tingkat kepuasan kerja karyawan PT X melalui alat ukur job satisfaction scale Widyakala 3(2) 9-22

[9] Rosita T and Yuniati T 2016 Pengaruh kepuasan kerja terhadap kinerja karyawan dengan komitmen organisasional sebagai variabel intervening Ilmu dan Riset Manajemen 5(1) 1-20

[10] Robbins S P and Judge TA 2009 Organization Behavior, Thirteenth Edition (New Jersey: Pearson Prentice Hall) 118-119

[11] Miles M B, Huberman A M and Saldaña J 2014 Qualitative Data Analysis: A Methods Sourcebook, Third Edition (Los Angeles: SAGE Publications, Inc.)

[12] Kara M 2012 Pemikiran Al-Syatibi tentang maslahah dan implementasinya dalam pengembangan ekonomi syariah ASSETS 2(2) 173-184

[13] Reza M and Violita E S 2018 Pengaruh penerapan nilai-nilai islam terhadap kinerja maqashid index pada bank syariah: Studi lintas negara Jurnal Dinamika Akuntansi dan Bisnis 5(1) 17-30 